\title{
Udział przedstawicieli pedagogiki i socjologii z Uniwersytetu Łódzkiego w dyskusji o rozwoju szkół wyższych w świetle artykułów „Życia Szkoły Wyższej” (1953-1973)
}

Jesienią 1944 r. w Lublinie rozpoczął się proces odbudowy szkolnictwa wyższego w Polsce wyzwalanej spod okupacji hitlerowskiej. Najpierw reaktywowano prywatną uczelnię - Katolicki Uniwersytet Lubelski, a następnie utworzono uniwersytet państwowy, który miał się stać symbolem odradzającej się nauki polskiej. W roku akademickim 1945/1946 uruchomiono szkoły wyższe z okresu międzywojennego oraz powołano szereg nowych placówek. Do tych ostatnich należał Uniwersytet Łódzki. Działania władz oświatowych doprowadziły do tego, że w roku akademickim 1945/1946 funkcjonowało 30 szkół wyższych, w których studia podjęło 55 tysięcy studentów 1 .

W początkowej fazie odbudowy szkolnictwa akademickiego określanie funkcji wyższego wykształcenia kształtowało się w oparciu o tradycję okresu międzywojennego. W dużej mierze władze oświatowe nawiązywały do liberalnej koncepcji szkolnictwa wyższego. Starano się jednak określać zadania szkół, uwzględniając przemiany społeczno-polityczne ${ }^{2}$.

Kolejne akty prawne wydawane w latach 40 . XX w. świadczyły o wprowadzaniu zasadniczych zmian w funkcjonowaniu szkół wyższych. Nowy kierunek

* Dr, Katedra Historii Wychowania i Pedeutologii, Wydział Nauk o Wychowaniu, Uniwersytet Łódzki, 91-408 Łódź, ul. Pomorska 46/48.

1 Historia wychowania. Wiek XX, t. 1, red. J. Miąso, Warszawa 1980, s. 325.

2 J. Szczepański, Socjologiczne zagadnienia wyższego wykształcenia, Warszawa 1963, s. $23-24$. 
rozwoju edukacji i nową organizację szkolnictwa wyższego wprowadziła ustawa z 15 grudnia 1951 r. ${ }^{3}$ Określała ona zadania dydaktyczno-naukowe i wychowawcze szkół wyższych w warunkach socjalistycznej przebudowy kraju. Najważniejszą instytucją, która miała zająć się rozwijaniem nauki i koordynowaniem prac badawczych prowadzonych przez wszystkie placówki naukowe w kraju stała się Polska Akademia Nauk, utworzona 30 października 1951 r.

W pierwszych latach kształtowania nowych struktur szkolnictwa wyższego najważniejszym dla szkół akademickich czasopismem stało się „Życie Nauki”. Zaczęło ono ukazywać się w Krakowie w styczniu 1946 r., z inicjatywy asystentów i adiunktów skupionych w Konwersatorium Naukoznawczym pod kierownictwem Mieczysława Choynowskiego ${ }^{4}$. Autorzy artykułów zamieszczanych w „Życiu Nauki”, reprezentujący różne dziedziny, pragnęli szerzyć wiedzę o nauce we wszystkich jej aspektach: od strony metodologicznej, historycznej, socjologicznej i organizacyjnej.

W 1947 r. nowym redaktorem został historyk, Bogusław Leśnodorski. Zmianie uległo niebawem miejsce wydawania pisma. Redakcja została przeniesiona do Warszawy. Pojawił się wówczas podtytuł: „Miesięcznik poświęcony zagadnieniom nauki i nauczania w szkołach wyższych, społecznej roli nauki i jej organizacji oraz sprawom Sekcji Szkół Wyższych Związku Nauczycielstwa Polskiego"5.

W latach 1950-1951 „Życie Nauki” spełniało rolę organu I Kongresu Nauki Polskiej, głosząc hasło Kongresu: nauka w służbie narodu. W następnym roku nastąpiła próba rozszerzenia zadań czasopisma poprzez wprowadzanie treści dotyczących procesu dydaktyczno-wychowawczego, mającego miejsce w szkołach wyższych. Ostatecznie w 1952 r. Departament Nauki Ministerstwa Oświaty przestał wydawać „Życie Nauki”. Czasopismo zlikwidowano, gdyż - zdaniem władz edukacyjnych - nie ustrzegło się błędów ideologicznych. Do najważniejszych należały: tendencje kosmopolityczne i „skupienie głównej uwagi na technice pracy naukowej w oderwaniu od treści poznawczych"6.

W 1953 r. ukazał się pierwszy numer czasopisma „Życie Szkoły Wyższej”. W artykule wstępnym pt. Na nowym etapie określono idee przyświecające Redakcji. Miesięcznik miał odzwierciedlać „bujne życie wyższych uczelni” i budzić „twórcze zainteresowanie” dla niedocenionej do tej pory problematyki dydaktycznej i wychowawczej ${ }^{7}$. Wyeksponowanie tematyki związanej z funkcją dydaktyczno-wychowawczą uczelni nie prowadziło więc do rezygnacji z problematyki naukowej.

${ }^{3}$ Dz. U. z 1952, nr 6, poz. 38.

${ }_{4}^{4}$ Mieczysław Choynowski (1909-2001) - psycholog, filozof, naukoznawca. W latach 1959-1969 był kierownikiem Pracowni Psychometrycznej PAN. Od 1972 r. przebywał w Meksyku, gdzie zajął się metodologią nauk psychologicznych.

${ }^{5}$ S. M o ż dż én, J. M u s i ał, Bibliografia polskich czasopism pedagogicznych (do 1979 r.), Kielce 1981 , s. 227-228.

6 Pierwsze posiedzenie Rady Redakcyjnej „Życia Szkoły Wyższej”, „Życie Szkoły Wyższej” [dalej: ŻSW] 1953, nr 7-8, s. 161.

7 J. Z. Ja ku bowski, Wobec nowych zadań, ŻSW 1961, nr 5, s. 20. 
Pierwszym redaktorem „Życia Szkoły Wyższej” został Jan Zygmunt Jakubowski, historyk literatury, profesor Uniwersytetu Warszawskiego. W Komitecie Redakcyjnym ważną rolę odgrywała Zofia Kietlińska, przewodnicząca ZOZ ZNP przy Uniwersytecie Warszawskim. W Radzie Redakcyjnej, obok polityków oświatowych, znaleźli się wybitni przedstawiciele nauki: Zenon Klemensiewicz, Bogusław Leśnodorski, Tadeusz Manteuffel i Adam Schaff ${ }^{8}$.

Cele czasopisma zostały sformułowane następująco:

- Współudział w realizacji polityki władz państwowych i kierowniczych organów ZNP w szkolnictwie wyższym.

- Informowanie pracowników szkół wyższych o zamierzeniach władz szkolnictwa wyższego i ZNP, o ich stanowisku w odniesieniu do węzłowych zagadnień pracy szkoły.

- Upowszechnianie i wymiana doświadczeń z pracy zawodowej: dydaktyczno-wychowawczej, naukowo-badawczej, organizacyjnej oraz pracy społecznej i politycznej.

- Informowanie o tendencjach rozwoju uczelni wyższych za granicą.

- Obrona interesów zawodowych i materialnych pracowników szkoły wyższej9.

Autorami publikacji zamieszczanych w miesięczniku byli reprezentanci różnych kierunków i specjalności w szkolnictwie wyższym. Dołączyli do nich przedstawiciele Resortu Szkolnictwa Wyższego, Rady Głównej Szkolnictwa Wyższego, ZNP. Nadsyłali artykuły autorzy zagraniczni.

W miesięczniku „Życie Szkoły Wyższej” wyodrębniono następujące działy:

1. Ogólny - zawierał informacje o regulacjach prawnych dotyczących szkolnictwa wyższego, prezentował stanowiska przedstawicieli władz oświatowych i związków zawodowych związane z kierunkiem polityki szkolnej w PRL, zaczerpnięte z okolicznościowych przemówień.

2. „Problemy i doświadczenia” - przedstawiał zagadnienia wychowawczo-dydaktyczne uniwersytetu, politechniki, szkoły ekonomicznej, akademii medycznej, szkoły rolniczej.

3. „Nauka i szkoły wyższe za granicą” - charakteryzował tendencje rozwoju szkół wyższych w krajach socjalistycznych i kapitalistycznych. Najwięcej miejsca przeznaczano dla tekstów autorów z krajów socjalistycznych.

4. „Sprawozdania i kronika” - informował o życiu naukowym, wychowawczym i dydaktycznym wyższych szkół, głównie o konferencjach naukowych i dydaktycznych.

5. „Recenzje” - dotyczyły wybranych monografii i wydawnictw zbiorowych, napisanych przez pracowników wyższych uczelni.

Taki układ treści utrzymał się przez pierwsze 20 lat istnienia miesięcznika. Redakcja dążyła do udoskonalenia pisma. Pierwsza ważna narada dotycząca tej kwestii została zorganizowana w listopadzie 1956 r. Zaproszono na nią redaktorów czasopism uczelnianych oraz przedstawicieli Ministerstwa Szkolnictwa Wyższego i związków zawodowych. Uczestnicy spotkania, oceniając czasopismo, dostrzegli

${ }^{8}$ Rada Redakcyjna, ŻSW 1953, nr 1, s. 2.

${ }^{9}$ K. Kąk ol, W poszukiwaniu dróg podniesienia wartości „Życia Szkoły Wyższej”, ŻSW 1956, nr 1, s. 95. 
szereg mankamentów, które - ich zdaniem - miały wpływ na małą popularność „Życia Szkoły Wyższej” wśród pracowników uczelni. Zwrócili uwagę na daleko posuniętą akademickość pisma, unikanie tematów trudnych i drażliwych (płace, sytuacja mieszkaniowa, działalność Centralnej Komisji Kwalifikacyjnej). Negatywnie ocenili jego „ministerialność”, która stanowiła zaporę dla bezpośrednich kontaktów z czytelnikami ${ }^{10}$.

Okazją do oceniania dorobku czasopisma stały się kolejne jubileusze obchodzone przez Redakcję. W 1961 r. nowy redaktor, Jan Legowicz, dokonał podsumowania wysiłku autorów i wydawców miesięcznika z okazji wydania setnego numeru ${ }^{11}$. Uważał, że podobnie jak zmienia się polskie szkolnictwo wyższe, unowocześniając pracę naukowo-badawczą i dydaktyczno-wychowawczą, tak również wzbogaca się tematyka czasopisma. „Życie Szkoły Wyższej” włączyło się w nurt spraw istotnych dla szkolnictwa wyższego, pomagało rozwiązywać podstawowe zagadnienia dotyczące organizacji i pracy szkół, dawało możliwość wzajemnej wymiany doświadczeń, popularyzowało nowe metody pracy w uczelniach. Zdaniem J. Legowicza, w najbliższej przyszłości (oprócz problematyki dydaktyczno-wychowawczej) na łamach miesięcznika należało zająć się sprawą planów badań naukowych i kwestią doboru i szkolenia młodej kadry naukowej ${ }^{12}$.

Autorzy z różnych ośrodków uczelnianych zwracali uwagę na zalety i wady pisma z okazji 15- i 20-lecia działalności „Życia Szkoły Wyższej”. Ważnym momentem stało się pojawienie „konkurenta” w postaci „Dydaktyki Szkoły Wyższej”13. Czasopismo to w formie kwartalnika miało poruszać problemy unowocześnienia procesów dydaktycznych w szkołach wyższych. W związku z zaistniałą sytuacją Wincenty Okoń widział „potrzebę znalezienia jakiejś względnej linii demarkacyjnej między dwoma czasopismami” i starał się określić nową rolę „Życia Szkoły Wyższej"14. Uważał, że miesięcznik powinien skupić się na następujących zagadnieniach: historia szkół wyższych i powstawanie szkół naukowych, rola społeczno-kulturowa wyższych uczelni, kształcenie specjalistów z wyższym wykształceniem oraz problemy wychowawcze (organizacja pracy wychowawczej przez pracowników uczelni, rola kół naukowych i organizacji społeczno-politycznych).

W tym samym numerze miesięcznika J. Legowicz stwierdzał, że „Życie Szkoły Wyższej” w latach 60. zyskało na popularności i stało się dla wielu pracowników dydaktyczno-naukowych swego rodzaju „vademecum”. W opinii Legowicza pismo „nie ma jakiegoś własnego «życia» wypreparowanego jedynie koncepcyjnie w gronie redakcyjnym. Jego egzystencja i funkcja pozostawała ściśle uzależniona od życia szkoły wyższej przeżywanego, sygnalizowanego i analizowanego przez autorów piszących do miesięcznika"15.

10 Tamże, s. 96-97.

11 J. L e g o w i c z, Z perspektywy stu numerów, ŻSW 1961, nr 5, s. 17-20.

12 Tamże, s. 19.

13 S. M oż dż én, J. M u s i ał, Bibliografia..., s. 49. Pierwszy numer „Dydaktyki Szkoły Wyższej” ukazał się w 1968 r. Wydawcą było Ministerstwo Oświaty i Szkolnictwa Wyższego. Redaktorem mianowano Włodzimierza Michajłowa. W 1969 r. redakcję objęła Zofia Kietlińska.

14 J. Le g o w i c z, O nowej roli „Życia Szkoły Wyższej”, ŻSW 1967, nr 12, s. 37.

15 J. Le go w i c z, „Życie Szkoły Wyższej” w perspektywie przeszłości i przyszłości, ŻSW 1967, nr 12, s. 3-5. 
Na łamach czasopisma „Życie Szkoły Wyższej” od 1953 r. ukazywały się artykuły pracowników naukowo-dydaktycznych UŁ. W dziale „Sprawozdania i kronika” przedstawiano uczestnictwo przedstawicieli łódzkiego środowiska w konferencjach dotyczących rozwoju szkół wyższych. Brali w nich udział kolejni rektorzy i dziekani. Największą aktywność na tym polu wykazywali reprezentanci dyscyplin humanistycznych i społecznych. Rzadko wypowiadali się przedstawiciele nauk matematyczno-przyrodniczych.

Artykuły zamieszczane w dziale „Problemy i doświadczenia” przygotowywali pracownicy pełniący $w$ UŁ rozmaite funkcje, mający różne stopnie naukowe. W latach 1953-1973 największa liczba publikacji wyszła spod pióra socjologów, prawników i pedagogów. Czwarte miejsce w tej klasyfikacji zajęli historycy. Dwa lub trzy artykuły mieli na swym koncie przedstawiciele bibliotekoznawstwa, filologii polskiej, geografii i biologiii' ${ }^{16}$.

Najbardziej zróżnicowane tematycznie były wypowiedzi pracowników UŁ reprezentujących pedagogikę. Osoby zatrudnione w zakładach i katedrach pedagogiki wypowiedziały swoje poglądy w sprawach rozwoju szkół wyższych w 13 publikacjach. W latach 50 . ukazały się tylko 2 artykuły, w latach 60 . - 6, a na początku lat 70. - 5. Prezentowane dane świadczą o rosnącej aktywności twórczej łódzkiego akademickiego środowiska pedagogicznego.

Nauki o wychowaniu przeżyły rozkwit w pierwszych latach istnienia UŁ. W ramach Wydziału Humanistycznego działały 4 katedry pedagogiki i 3 psychologii. Stanowiska kierownicze sprawowali profesorzy mający znaczący dorobek naukowy i bogate doświadczenia w pracy dydaktyczno-wychowawczej, tacy jak: Sergiusz Hessen, Maria Librachowa, Helena Radlińska, Stefan Truchim. Wokół nich skupiła się licznie reprezentowana młoda kadra naukowa ${ }^{17}$. Studia na kierunku pedagogika odbywała najliczniejsza grupa studentów UŁ.

Na początku lat 50 . w UŁ nastąpiły zasadnicze zmiany organizacyjne i nieodwracalne zmiany personalne. W ramach nowo utworzonego Wydziału Filozoficzno-Historycznego powołano do życia zespół katedr pedagogiki i psychologii. Był on nieliczny, gdyż duża grupa profesorów i pracowników pomocniczych została usunięta z uczelni. Pedagogika podzieliła losy innych kierunków humanistycznych i została zlikwidowana. Reaktywowano ją w UŁ dopiero w 1959 r. ${ }^{18}$

Znajomość tych faktów jest niezbędna, gdy charakteryzujemy działalność naukową i dydaktyczno-wychowawczą łódzkich pedagogów w latach 50 . Ich najważniejszym zadaniem stało się wówczas prowadzenie zajęć z pedagogiki na kierunkach nauczycielskich.

W 1953 r. mgr Franciszek Czerwiński, prowadząc ćwiczenia z pedagogiki ze studentami biologii, geografii i historii, zebrał od nich opinie na temat organizacji

${ }^{16}$ S. Skwirows ka, „Życie Szkoły Wyższej”. Bibliografia zawartości (1953-1967), Warszawa 1969 oraz kwerenda „Życia Szkoły Wyższej” przeprowadzona przez Autorkę.

17 Rozprawy doktorskie z pedagogiki na Wydziale Humanistycznym UŁ napisali: Helena Brodowska, Aleksander Kamiński, Karol Kotłowski, Irena Lepalczyk, Wincenty Okoń, Eugenia Podgórska, Wiktor Szczerba.

${ }^{18}$ E. Witk owska-Urban, Nauki o wychowaniu w Uniwersytecie Łódzkim w latach 19452010, [w:] Edukacja - Regiony - Regionalizacja. Program rozwoju Wydziału Nauk o Wychowaniu w ramach strategii rozwoju Uniwersytetu Łódzkiego. Raport 2009, red. M. Kulesza, Łódź 2010, s. 39-62. 
i przebiegu egzaminów na wyższej uczelni. Uzyskane dane wykorzystał do napisania artykułu pt. Egzamin jako ważne zagadnienie w dydaktyce uniwersyteckiej. Swoistym znamieniem czasu stało się dołączenie do odpowiedzi studentów, sądów wypowiadanych $w$ trakcie dyskusji na zebraniu podstawowej organizacji partyjnej na wydziale. Zdaniem członków PZPR, do istoty trudności pojawiających się na egzaminach przeprowadzający je mogą dotrzeć, „stosując uczciwą krytykę i samokrytykę"19.

W 1957 r. prof. dr S. Truchim wypowiedział się na temat pedagogizacji na kierunkach nauczycielskich. Krytycznie odniósł się do praktyk stosowanych w uczelniach, które lekceważą często pedagogikę i na zajęcia z tego przedmiotu przeznaczają mało czasu. Ponieważ od 1 października 1957 r. następowała zmiana programów, Truchim apelował do władz szkół wyższych, aby zainteresowały się pedagogizacją w podległych im placówkach. Przedstawił swoją koncepcję pedagogizacji. Uważał, że w każdej uczelni powinno zostać powołane specjalne studium, które realizowałoby nauczanie przedmiotów pedagogicznych w trakcie studiów kierunkowych. Przewidywał bogaty program obejmujący 10 przedmiotów. Zajęcia z nich odbywałyby się od I do IV roku studiów. Egzamin zdany w studium pedagogizacji i odbyta praktyka pedagogiczna stanowić powinny podstawę do otrzymania dyplomu nauczyciela szkoły średniej ${ }^{20}$.

Dziesięć lat później w sprawie pedagogizacji zabrał głos mgr Jan Wiktor. Odwołał się do własnych doświadczeń w UŁ i przedstawił uwagi i sugestie metodyczne dotyczące prowadzenia ćwiczeń z pedagogiki na kierunkach nauczycielskich. Określił formy pracy indywidualnej i zespołowej, dobór materiału, metody kontroli studentów. Wskazał, jak hospitacje w szkołach przekształcić w rzeczywisty czynnik kształcenia pedagogicznego 21.

Pracownicy katedr pedagogiki w UŁ żywo interesowali się sprawą kształcenia młodej kadry naukowej. Doc. dr Karol Kotłowski wziął udział w krajowej konferencji, którą Ministerstwo Szkolnictwa Wyższego zorganizowało na wiosnę $1962 \mathrm{r}$. w Warszawie. W swym wystąpieniu scharakteryzował program realizowany w Uk. Wskazał najważniejsze tematy, które występowały na wykładach i konwersatoriach przeznaczonych dla asystentów ${ }^{22}$.

Na początku lat 70. powyższy temat powrócił na strony „Życia Szkoły Wyższej”. Wówczas włączył się do dyskusji doc. dr Kazimierz Sporny z UŁ. W publikacji starał się udzielić odpowiedzi na pytania, jaki powinien być program szkolenia asystentów i jak dopomóc młodym pracownikom w zdobywaniu mistrzostwa pedagogicznego. Uznał za celowe tworzenie w uczelniach międzywydziałowych zakładów pedagogicznych, które nie tylko szkoliłyby młodą kadrę, lecz upowszechniałyby nowe metody i techniki nauczania, kierowały organizacją praktyk

19 F. C z e rw i ń s k i, Egzamin jako ważne zagadnienie w dydaktyce uniwersyteckiej, ŻSW 1953, $\mathrm{nr} 7 / 8$, s. 92.

20 S. Tru c h i m, Zagadnienie pedagogizacji na uniwersytetach, ŻSW 1957, nr 4, s. 53-56.

21 J. Wiktor, Uwagi o prowadzeniu ćwiczeń z elementów nauk pedagogicznych, ŻSW 1967, nr 3, s. 64-68.

${ }^{22}$ K. Ko łło w s k i, Głos w dyskusji. Krajowa konferencja w sprawie pedagogizacji młodej kadry, ŻSW 1962, nr 7/8, s. 60-61. 
pedagogicznych. Jego zdaniem, najbardziej słuszna była koncepcja planowego i systematycznego szkolenia asystentów, a nie jedynie ich samokształcenie. Przedstawił swój pomysł programu szkolenia ${ }^{23}$.

Doświadczeniami z pracy w Katedrze Pedagogiki Społecznej UŁ dzieliła się na łamach miesięcznika doc. dr hab. Irena Lepalczyk. W 1969 r. dokonała podsumowania działalności konwersatoriów, które w jej katedrze przybrały postać kształcenia podyplomowego. Konwersatorium stanowiło drogę do rozwoju zainteresowań naukowych i zawodowych. Uczestnikami comiesięcznych spotkań byli nie tylko absolwenci pedagogiki ${ }^{24}$. W 1970 r. I. Lepalczyk napisała artykuł o praktykach studentów pedagogiki, prowadzonych w placówkach pozaszkolnych. Były one przeznaczone dla studentów III i V roku pedagogiki. Pierwsze miały charakter dydaktyczny, „asystencki”, drugie zawierały elementy badawcze i społeczne. Praktyki były w Katedrze Pedagogiki Społecznej traktowane nie tylko jako forma kształcenia, lecz także jako droga wprowadzająca studenta w życie społeczne ${ }^{25}$.

Asystenci z katedr pedagogicznych UŁ przedstawiali na łamach „Życia Szkoły Wyższej" swe spostrzeżenia i refleksje związane z pełnieniem funkcji opiekuna obozu naukowego i opiekuna I roku' ${ }^{26}$. Ich wypowiedzi nawiązywały do dyskusji zainicjowanej przez Redakcję miesięcznika, dotyczącej problemów wychowawczych pojawiających się w szkołach wyższych.

Przykładem artykułu napisanego na prośbę Redakcji „Życia Szkoły Wyższej” była obszerna wypowiedź doc. dr. Karola Kotłowskiego na temat roli wykładów w procesie dydaktyczno-wychowawczym uczelni wyższych ${ }^{27}$. Opierając się na obserwacji i własnych doświadczeniach autor stwierdził, że studentów cechuje niski stan kultury języka, który jest wskaźnikiem braku dyscypliny myślenia i poziomu kultury w ogóle. Za taki stan rzeczy winił w dużej mierze środowisko rodzinne i współczesny program nauczania, obowiązujący w szkołach podstawowych i średnich. Autor starał się wskazać wykładowcom, jak powinni doskonalić metody pracy ze studentami, aby zlikwidować widoczne braki. Skupiając się na wykładach kursowych i monograficznych na kierunkach humanistycznych, podawał wskazówki dotyczące ich przygotowania i prowadzenia. Proponował przekształcenie części wykładów w konwersatoria, co stwarzałoby możliwość współuczestniczenia studentów w dyskusji naukowej.

$Z$ kolei doc. dr hab. Roman Polny wypowiedział się na łamach miesięcznika na temat teorii podręcznika akademickiego ${ }^{28}$. Jego zdaniem, podręcznik to nie tylko źródło wiedzy, którą należy przyjąć, to także narzędzie pozwalające

${ }^{23}$ K. S p o rn y, Głos w dyskusji w sprawie kształcenia pedagogicznego asystentów, ŻSW 1971, nr 2, s. 96-100.

${ }_{24}$ I. L e p a l c z y k, Kształcenie podyplomowe absolwentów pedagogiki, ŻSW 1969, nr 12, s. 92-96.

${ }^{25}$ I. Le palc zy k, Praktyki studentów pedagogiki, ŻSW 1970, nr 6, s. 93-97.

${ }^{26}$ D. Greulich, Uwagi na temat organizacji obozu naukowego, ŻSW 1967, nr 6/7, s. 135138; M. K u ź n i k, Pierwsze kroki - relacja z badań przeprowadzonych wśród studentów I roku, ŻSW 1971, nr 11, s. 109-115.

${ }^{27}$ K. Kotłowski, Problem intelektualnej aktywizacji studenta na wykładach, ŻSW 1960, nr 7/8, s. 55-69.

${ }^{28}$ R. Poln y, W kwestii teorii podręcznika akademickiego, ŻSW 1973, nr 10, s. 69-75. 
przetwarzać ją w wartości decydujące o dojrzałości uczącego się. W związku z tym podręcznik oprócz tekstu powinien zawierać zadania, które pozwolą kształtować umiejętności rozpoznawania, wartościowania, planowania i samokształcenia studentów. R. Polny twierdził, że nie można wprowadzać jednolitych kryteriów budowy podręczników. Pojawiające się w procesie kształcenia różne formy kierowania procesem dydaktycznym (prowadzący jako instruktor, organizator, konsultant, opiniodawca) wymagają odpowiedniego podręcznika.

Z przedstawionej charakterystyki wynika, że dopiero w latach 60. i na początku 70. wzrosła aktywność pracowników dydaktyczno-naukowych reprezentujących pedagogikę UŁ. Na łamach „Życia Szkoły Wyższej” coraz częściej ukazywały się artykuły teoretyków wychowania, dydaktyków i pedagogów społecznych z łódzkiej uczelni. Większość publikacji była autorstwa pracowników samodzielnych.

Po trudnych latach 50. pedagogika na UŁ (jako kierunek studiów, ale także jako nauka społeczna) zaczęła zyskiwać znaczenie. Wzrosła liczebnie kadra w poszczególnych zakładach i katedrach. Zróżnicowane zainteresowania badawcze pracowników dydaktyczno-naukowych uwidoczniły się w postaci licznych publikacji. Część z nich drukowano na łamach „Życia Szkoły Wyższej”.

W charakteryzowanym czasopiśmie nauki społeczne obok pedagogów reprezentowali socjolodzy. W latach 50. i 60.najczęściej na temat funkcjonowania szkół wyższych wypowiadał się Jan Szczepański ${ }^{29}$, który został zatrudniony w UŁ w 1945 r. Dołączył do grona badaczy kontynuujących wcześniejsze kierunki socjologii (socjologia humanistyczna) oraz zajmujących się nowymi zjawiskami i procesami społecznymi, zachodzącymi w Polsce po 1945 r. (Józef Chałasiński). Pracował na Wydziale Humanistycznym, gdzie w 1949 r. otrzymał stopień doktora habilitowanego na podstawie dysertacji Ustalanie faktów społecznych w socjologii i psychologii społecznej30.

Po 1949 r. w UŁ nastąpiła likwidacja socjologii jako odrębnej dyscypliny naukowej. Problemy rozwoju społecznego włączono do filozofii, historii i etnografii. W latach 1949-1952 „dziedzictwo socjologiczne przeszłości zostało w całości odrzucone jako nadbudowa ideologiczna kapitalizmu i zastąpione kanonem marksistowskiej wiedzy o społeczeństwie, przygotowanym i narzuconym przez władze"31. Stopniowo po 1956 r. nastąpiło odrodzenie socjologii jako nauki. Na UŁ reaktywowano studia na tym kierunku.

W latach 50. i 60. prof. dr hab. J. Szczepański pełnił w UŁ szereg funkcji: kierownika zakładu, katedry, prodziekana, a w latach 1952-1956 - rektora ${ }^{32}$. Łódz-

${ }^{29}$ L. M i a s tkow ski, Sylwetki łódzkich uczonych. Od Wolnej Wszechnicy Polskiej do wydziału Ekonomiczno-Socjologicznego Uniwersytetu Łódzkiego, Łódź 1995, s. 236-237. Jan Szczepański (1913-2004) studia w zakresie socjologii i filozofii odbył w latach 1932-1936 na Uniwersytecie im. Adama Mickiewicz w Poznaniu. W 1939 r. w tej uczelni otrzymał stopień doktora filozofii z zakresu socjologii na podstawie rozprawy Pojęcie środowiska w socjologii wsi. Promotorem pracy był prof. Florian Znaniecki.

30 Tamże, s. 236.

31 J. Ku r czew ska, Socjologia, [w:] Humanistyka polska w latach 1945-1990, red. U. Jakubowska, J. Myśliński, Warszawa 2000, s. 104-105.

32 L. M i a s tk ow s ki, Sylwetki..., s. 236-238. 
ką uczelnię opuścił w 1970 r. Na łamach „Życia Szkoły Wyższej” zadebiutował w 1953 r. publikacją dotyczącą narad produkcyjnych w UŁ ${ }^{33}$. Miały one stanowić jedną z nowych form pracy dydaktycznej i organizacyjnej przyczyniającą się do realizowania zadań w ramach nowych programów studiów. Działo się to w okresie planu 6-letniego, gdy uniwersytet stawał się swoistym zakładem produkcyjnym, w którym narady miały mobilizować profesorów i studentów do wykonania planów. Szczepański surowo oceniał narady, na których walka o ideologiczne treści nauczania sprowadzała się do „ostrej krytyki profesorów ze strony nie zawsze kompetentnych studentów"34. Był jednak przeciwnikiem likwidacji narad. Uważał, że mogą dopomóc w przygotowaniu usprawnień pracy uczelni pod warunkiem, że zostaną dobrze przygotowane i przeprowadzone. Władze uniwersytetu muszą zatroszczyć się o wprowadzenie w życie uchwał i wniosków z tychże narad.

W okresie pełnienia funkcji rektora UŁ, prof. J. Szczepański niejednokrotnie uczestniczył w konferencjach władz polskich szkół wyższych z przedstawicielami Ministerstwa Szkolnictwa Wyższego. Miesięcznik „Życie Szkoły Wyższej” służył prezentacji przebiegu dyskusji prowadzonych na tych konferencjach. Często cytowano wypowiedzi łódzkiego naukowca. W wielowątkowej dyskusji na konferencji rektorów i dziekanów w 1954 r. prof. Szczepański dowodził (biorąc pod uwage wybrane zakłady w UŁ), że jakość absolwentów zależy od jakości kadry nauczającej. Jego zdaniem zespołowa praca pod kierunkiem twórczego profesora, wysoki poziom metodologiczny, realny plan pracy, odpowiednie lokale i ich wyposażenie decydująco wpłynęły na wysoką jakość kształcenia ${ }^{35}$. Zwracał uwagę na czynniki wychowawcze w uczelni. Zaliczał do nich: koła naukowe, organizację partyjną, ZMP, studium wojskowe. Zadaniem kadry dydaktyczno-naukowej powinno być kształtowanie twórczego stosunku do nauki studentów. Przyswojona wiedza ma pobudzać do myślenia, stawiania pytań, szukania odpowiedzi i wyciągania wniosków. Tylko takie działania doprowadzą do ukształtowania się właściwego poglądu na świat ${ }^{36}$. W części poświęconej kwestii przygotowania absolwentów uczelni wyższych do pracy łódzki naukowiec skupił się na charakterystyce kształcenia uniwersyteckiego w odróżnieniu od innych szkół wyższych. Uważał, że tylko kontakt uczelni z absolwentami i zakładami pracy może wpłynąć na wprowadzenie korekt do programów i zmiany metod kształcenia ${ }^{37}$.

Pod koniec 1955 r. Redakcja „Życia Szkoły Wyższej” zainicjowała dyskusję nad rolą i funkcją uniwersytetu w systemie szkolnictwa PRL i w całym naszym życiu kulturalnym. Zaczynem do dyskusji stał się artykuł prof. Szczepańskiego pt. Problemy współczesnych uniwersytetów.

Pierwsza część publikacji miała charakter historyczny. Autor, opierając się na współczesnej mu literaturze anglojęzycznej i niemieckojęzycznej, scharakteryzował

${ }^{33}$ J. S z c z e p a ń s ki, Na Uniwersytecie Łódzkim. Narady produkcyjne, ŻsW 1953, nr 3, s. 41-44.

34 Tamże, s. 41.

35 J. Szczepański, Konferencja rektorów i dziekanów. Głos w dyskusji, ŻsW 1954, nr 3 , s. 88-89.

36 Tamże, s. 75.

${ }^{37}$ Tamże, s. 105-106. 
rozwój uniwersytetu XIX-wiecznego, zwanego liberalnym. Następnie wskazał czynniki, które w pierwszej połowie XX w. doprowadziły do kryzysu zasad moralnych i ideologicznych w uczelniach na zachodzie Europy. W drugiej części artykułu prof. Szczepański podjął próbę określenia, jak polskie uniwersytety powinny dostosowywać się do nowych realiów polityczno-społecznych po 1945 r. Zwrócił uwagę na wpływ ideologii marksizmu-leninizmu na wychowanie młodzieży, potrzebę znalezienia równowagi między wykształceniem ogólnym a specjalizacją, problem kształcenia młodych pracowników nauki. Pisał: „błędem byłoby sądzić, że świat kapitalistyczny znajduje się w impasie i biernie czeka, co przyniesie los! Wręcz przeciwnie, rozwija on olbrzymią działalność"38. Dalej autor artykułu radził, aby Polacy, nawiązując do wzorów zachodnioeuropejskich i radzieckich, stworzyli koncepcję nowego uniwersytetu. Powinien on stać się „syntezą osiągnięć uniwersytetu liberalnego, ideologii socjalistycznej i nowych form pracy dydaktyczno-wychowawczej"39.

W drugiej połowie lat 50. prof. Szczepański był w Sejmie zastępcą przewodniczącego komisji oświaty i nauki. Nabył tam wiedzę o mechanizmach działania administracji centralnej. Pozwoliło mu to w sposób kompetentny i rzeczowy wypowiadać się na łamach „Życia Szkoły Wyższej” na temat finansowania szkolnictwa wyższego ${ }^{40}$.

Pracując w UŁ prof. Szczepański kierowałPracownią Badań nad Szkolnictwem Wyższym powołaną przez Ministerstwo Szkolnictwa Wyższego oraz uczestniczył w badaniach Zakładu Badań Socjologicznych PAN. W publikacjach zamieszczanych w miesięczniku „Życie Szkoły Wyższej” wykorzystywał wyniki tych badań.

W artykułach występował jako przeciwnik uogólnień z powierzchownych obserwacji i przypadkowych spostrzeżeń. Zachęcał pedagogów i psychologów do badań empirycznych i eksperymentów. Przyjęcie takiej postawy przez badaczy reprezentujących nauki społeczne mogło doprowadzić do wyjaśnienia szeregu problemów, z którymi borykało się szkolnictwo wyższe.

Przykładem dla innych naukowców mogły stać się badania dotyczące doboru młodzieży na studia zgodnie z kryteriami klasowymi. Już na wstępie prof. Szczepański stwierdził, że zaliczenie kandydatów do odpowiednich klas społecznych było wątpliwe z punktu widzenia socjologicznej definicji klas. Przeprowadzona przez niego analiza życiorysów absolwentów UŁ wykazała, że pochodzenie społeczne nie było czynnikiem, który w sposób decydujący wpływał na postawy ideologiczne i przekonania społeczne. Postawy społeczne prezentowane przez nową inteligencję dowodziły, że „pochodzenie społeczne nie wpływa na stopień identyfikacji tej grupy z ustrojem socjalistycznym, identyfikację jej celów życiowych z celami tego ustroju"41.

\footnotetext{
${ }^{38}$ J. S z c ze p ań s ki, Problemy współczesnych uniwersytetów, ŻSW 1955, nr 12, s. 28.

${ }^{39}$ Tamże.

40 J. Szcze pański, Ustalamy rzeczywiste potrzeby finansowe szkolnictwa wyższego, ŻSW 1958, nr 4, s. 17-22.

${ }^{41}$ J. Szczepańs ki, Zadania uniwersytetów w perspektywie planu 15-letniego, ŻsW 1959,
} nr 10, s. 34 . 
Prof. Szczepański w swych publikacjach odnosił się do bieżących wydarzeń, mających miejsce w polskich szkołach wyższych. Po wypadkach marcowych w 1968 r. napisał obszerny artykuł dotyczący urzeczywistniania określonego ideału wychowawczego w działaniach podejmowanych na uczelni wyższej ${ }^{42}$. Autor uświadamiał czytelnikom, że na uczelniach polskich zmierza się do kształtowania postaw społecznych, politycznych, przekonań ideologicznych, które mają doprowadzić do tego, aby absolwenci byli nie tylko dobrymi fachowcami, lecz także aby swoje osobiste interesy potrafili i chcieli podporządkować interesom ustroju socjalistycznego. Starał się odpowiedzieć na pytania: jak ten cel osiągnąć, jakimi metodami mają posłużyć się wychowawcy, jakie sytuacje na uczelni i poza nią sprzyjają podejmowanym działaniom, a jakie je niweczą. Dokonując analizy procesu wychowawczego, doszedł do wniosku, że najważniejszym czynnikiem jest osobowość, indywidualność wychowawcy. Jego osobisty przykład, własna dyscyplina, autorytet naukowy mają wpływ na studenta. W polskich warunkach istotny jest przykład całego kolektywu nauczycielskiego.

Prof. Szczepański prowadził badania nad różnymi aspektami wyższego wykształcenia, ale też jako dziekan i rektor UŁ współuczestniczył w kształtowaniu struktur uczelni. Jak sam twierdzit: „socjologiczny punkt widzenia stosował do analizy własnej pracy praktycznej i do analizy procesów, w których uczestniczył" 43 . Jego wypowiedzi na łamach czasopisma „Życie Szkoły Wyższej” miały pobudzać do głębszej refleksji i dyskusji nad szkolnictwem wyższym.

Przedstawiciele pedagogiki w UŁ w latach 1953-1973 nie prowadzili szeroko zakrojonych badań nad szkolnictwem wyższym. W artykułach zamieszczanych w miesięczniku „Życie Szkoły Wyższej” dzielili się z czytelnikami swoimi doświadczeniami z działalności dydaktyczno-wychowawczej. Prezentowali rozwiązania, które mogły przyczynić się do podniesienia poziomu pracy uczelni wyższej.

42 J. Szczep ań s ki, Elementy procesu wychowawczego, ŻSW 1968, nr 11/12, s. 133-143.
43 J. S zczepańs ki, Socjologiczne zagadnienia..., s. 4 . 